\title{
CORRIGENDUM
}

\section{Not Isolated, Actively Isolationist: Towards a subaltern history of the Nilgiri hills before British imperialism}

GWENDOLYN I. O. KELLY

doi:10.1017/Soo26749X16000299. Published by Cambridge University Press, 3 May 2017.

In this article $^{1}$ the following errors appeared:

On page 1036, the 'third Anglo-Mysore War' should refer instead to the 'fourth Anglo-Mysore War'.

On page 1037, the statement 'by bringing together concepts drawn from Gramsci, Ramchandra Guha and the Subaltern Studies group' should read 'Ranajit Guha', not 'Ramchandra Guha'. Ranajit Guha was one of the founders of the Subaltern Studies group.

On page 1041, the statement 'Just as Ramchandra Guha and colleagues have argued' should again read 'Ranajit Guha' and not 'Ramchandra Guha'.

On page 1052 , footnote 46 'P. Hockings, "Identity in complex societies: are the Badagas caste or tribe?", Political Science Review, vol. 7 , 1968 ' is incorrect. The correct reference is: 'P. Hockings, "Identity in complex societies: are the Badagas caste or tribe?", Journal of African and Asian Studies, vol. 2, no. 2, 1968, pp. 29-35'.

The author would like to apologize to readers for these errors.

${ }^{1}$ G. Kelly, 'Not isolated, actively isolationist: towards a subaltern history of the Nilgiri hills before British imperialism', Modern Asian Studies, vol. 51, no. 4, 2017 , pp. 1035-1069. doi:10.1017/Soo26749X16000299 